\title{
Clinical aspects in the treatment planning for rehabilitation with overdenture and protocol-type prosthesis
}

\author{
Aspectos clínicos utilizados no planejamento de prótese overdenture e protocolo
}

Híttalo Carlos Rodrigues de ALMEIDA'

Ellane Talita Silvano de SANTANA ${ }^{1}$

Nikácio Adnner Tavares dos SANTOS ${ }^{1}$

Patrícia Karla Macedo de MORAES'

Yasmin Rafaelle Furtado de ARAÚJO'

Marleny Elizabeth Marquez de Martinez GERBI ${ }^{1}$

\section{ABSTRACT}

\section{Objective}

The aim of this study was to criticaly review the published literature regarding the clinical aspects involved in the rehabilitation of edentulous patients using Branemark protocol and overdenture prostheses.

\section{Methods}

An active search was conducted in the LILACS, MEDLINE, PubMed, and SciELO databases using the descriptors: "Coating for dentures" (Overlay Prosthesis and Overdenture) and "Implant-supported fixed dental prosthesis" (Protesis dental de suporte implantado, Dental prosthesis, and Implant Supported Prosthesis) in Portuguese, English, and Spanish between January 2000 and October 2014.

\section{Results}

The following parameters should be considered when selecting between Branemark protocol and overdenture prostheses: bone support, lip support, lip-line, upper lip length, oral mucosa conditions and size, alveolar ridge contour, crown-bone ratio, interarch space, and speaking space. Overdenture rehabilitation can provide many benefits to patients, such as prosthetic retention, stability, comfort, and improved aesthetics.

\section{Conclusions}

This study highlights the need for a thorough individualized treatment planning to ensure that fixed prostheses and overdentures have an excellent prognosis when used appropriately in suitable patients at the appropriate time.

Indexing terms: Denture overlay. Dental prosthesis, implant-supported. Mouth edentulous.

\section{RESUMO}

\section{Objetivo}

Verificar por meio de revisão crítica da literatura os aspectos clínicos durante o planejamento de pacientes edêntulos frente à utilização de próteses tipo protocolo de Branemark e overdenture.

\section{Métodos}

Busca ativa nas bases de dados LILACS, MEDLINE, PubMed e SciELO por meio dos descritores: "Revestimento de dentadura" (Prótese de Recobrimento e Overdenture) e "Prótese dentária fixada por implante" (Protesis dental de suporte implantado e Dental prosthesis, implant supported) entre janeiro de 2000 até outubro de 2014 nas línguas Portuguesa, Inglesa e Espanhola.

\section{Resultados}

Deve-se levar em consideração para indicar as próteses overdentures e protocolo o suporte ósseo, suporte labial, linha do sorriso, comprimento do lábio superior, qualidade e quantidade da mucosa, contorno do rebordo alveolar, relação coroa/osso, espaço interarcos e zona fonética. A reabilitação com overdenture pode trazer muitos benefícios ao paciente, tais como retenção, estabilidade, conforto, e a estética.

\section{Conclusões}

Evidencia-se a necessidade de um planejamento individualizado, para que se chegue a um correto plano de tratamento, no qual as próteses fixas e overdentures possam ter um excelente prognóstico, desde que utilizadas no momento apropriado e no paciente indicado.

Termos de indexação: Revestimento de dentadura. Prótese dentária fixada por implante. Boca edêntula.

${ }^{1}$ Universidade de Pernambuco, Faculdade de Odontologia. Av. General Newton Cavalcanti, 1650, Tabatinga, 54753-220, Camaragibe, PE. Brasil. Correspondência para / Correspondence to: HCR ALMEIDA. E-mail: <hittalor@gmail.com>. 


\section{INTRODUCTION}

Before dental implants became available, the only option for replacement of teeth in completely edentulous patients, both in the upper and lower arches, was the use of mucosa-supported dentures. Dental implants are a simpler, more efficient, and predictable alternative treatment to satisfy the needs and desires of patients'.

Osseointegration (or osteointegration) has been described by Branemark as "the direct structural and functional connection between ordered, living bone and the surface of a load-carrying implant" 2 . After the introduction of this concept, this author started replacing the root of missing teeth in the lower arch in edentulous patients by securing a fixed full denture using screws. This type of prosthesis is known as Branemark protocol-type prosthesis ${ }^{3}$.

The original technique has undergone some changes over time, and today there are a variety of prosthetic treatment options associated with dental implants for the total replacement of missing teeth in the mandible and maxilla $a^{2-4}$. Among them are the overdentures, which are total screw-retained implant-supported prostheses ${ }^{5-7}$.

The rehabilitation treatment using implantretained prosthesis provides more stability and retention ${ }^{4}$, improving mastication and decreasing the rate of ridge resorption ${ }^{5,8-9}$ compared with the treatment with conventional total prostheses. However, the use of removable implant-retained prostheses is a more timeand cost-effective treatment compared to the use of fixed implant-supported prostheses ${ }^{8-9}$.

The prosthetic planning to decide on the use of overdenture or protocol-type prosthesis must be thorough and based on the patient's oral conditions and expectations, taking into account anatomical, functional, and psychosocial factors ${ }^{10-11}$. Since prosthetic rehabilitation offers a wide range of therapeutic possibilities, these types of prostheses have become a challenge to dental surgeons ${ }^{4,6,8,12-13}$. Conventional total prostheses are mucosa-supported prostheses, but overdentures, for example, can be implant-retained combining the implant retention with the mucosa support, or they can be implant-supported, with the same biomechanical characteristics of implant-fixed prostheses with little to no mucosal support ${ }^{2-4,12}$.

The objective of this study was, through a literature review, to gather information about planning for prosthetic rehabilitation using Branemark protocol and overdenture prostheses aiming for an effective and successful treatment from a clinical point of view as well as in terms of the psycofuntional and psychosocial well-being of patients.

\section{METHODS}

\section{Databases and search strategy}

A search of the Portuguese, English, and Spanish literature was carried out in the LILACS, MEDLINE, PubMed, and ScIELO databases using the descriptors: "Coating for dentures" (Overlay Prosthesis and Overdenture) and "Implant or fixed dental prosthesis" (Implant supported prosthesis and Dental prosthesis) between January 2000 and October 2014.

\section{Studies included in the review}

The articles identified were evaluated by the authors according to the following inclusion criteria: full-text articles, search period (from January 2000 to October 2014), target population (aged 18-85 years), type of study (no limitation), and inclusion of systematic reviews, provided they address the study and comparison of Branemark protocol and overdenture prostheses during the surgical and prosthetic planning. The exclusion criteria were: in-vitro and/or laboratory studies; target population under the age of 18 years; review articles and studies published before or after the search period selected.

\section{RESULTS}

Considering the search by the descriptor "Overdenture" alone, 3,429 studies were identified using the database MEDLINE, 3,479 using PubMed, 133 using LILACS, and 102 using SciELO. Considering the search by the descriptor "Implant-supported fixed dental prosthesis" alone, 5,864 studies were identified using MEDLINE, 6,913 using PubMed, 392 using LILACS, and 83 using SCiELO. When searching by both descriptors "Overdenture" and "Implant-supported fixed dental prosthesis", 1,309 studies were identified using MEDLINE, 1,473 using PubMed, 37 using LILACS, and 25 using SciELO. After analyzing all of them, 26 studies and 2 dental implant databases were selected.

The anatomical factors that have the greatest influence on the maintenance and prognosis of any prosthetic rehabilitation using dental implants are bone quality and quantity ${ }^{13-17}$. The following parameters should be investigated during the extraoral and intraoral clinical examination to select the appropriate type of prosthesis 
to be used: lip support, smile line, upper lip length, oral mucosa conditions and size, alveolar ridge contour, crownbone ratio, interarch space, and speaking space ${ }^{18}$.

Overdenture rehabilitation can provide many benefits to patients, mainly better retention and stability at a much lower cost than protocol-type prosthesis rehabilitation. Moreover, in the scientific literature, the advantages of overdentures are also related the ease of cleaning and better restoration of facial profile ${ }^{12,15-16}$.

However, an overdenture prosthesis more carefully and accurately designed and fabricated than a protocol-type prosthesis has been reported in the literature $2,4-5,9-10,14,16$. Overdenture design and placement must include all parameters and factors used in conventional total prosthesis $2,4-5,9-10,14,16,18-19$. Among the overdenture retention attachments available, the bar-clip system provides greater degree of stability and therefore higher patient satisfaction ${ }^{10-12,16-17,19}$

With regard to psychosocial factors, it was found that comfort, stability, and aesthetics are some of the factors that demonstrate the satisfaction of patients rehabilitated with implant prosthesis as compared to conventional dentures ${ }^{19-22}$. However, most studies indicate that protocol-type prostheses appear to have a negative effect on the satisfaction of the patients rehabilitated with this type of prosthesis since the most important aspects to patients are aesthetics and phonetics ${ }^{21-22}$.

\section{DISCUSSION}

The reviewed studies showed that prostheses can be used to rehabilitate edentulous arches, whether they are implant prosthesis or conventional total prosthesis ${ }^{1,6,9}$ Combined implant-retained and soft tissue-supported overdentures can be used in cases when four or less dental implants had been placed ${ }^{2,4,13,16}$. In situations when it is possible to place a sufficient number of dental implants of an adequate length, the prosthetic superstructure can be implant-supported, and it is called protocol-type prosthesis ${ }^{19-20,22}$

As for the bone anatomy, in order for a suitable number of dental implants be placed in the ideal positioning there must be good bone quality (both width and height) ${ }^{14-17}$. Bone quality around the implant affects its resistance under mechanical loading conditions ${ }^{14,17}$. When there is poor bone quality, the loading should be reduced or the number of implants should be increased ${ }^{14-15}$. In terms of occlusion, prosthesis planning will be influenced by the type of restorative material, by the number, diameter, and length of the implants, and by the antagonist $\operatorname{arch}^{14-16 .}$

The treatment planning for rehabilitation with overdenture or protocol-type prosthesis is based on the mechanical loading it will be subjected to ${ }^{14}$. Depending on the selection of the system attachments, the retention attachments, and the scattering of the spreading of the implants, the bite force exerted by the overdenture on the implants and on peri-implant bone as well as the amount of force that will be absorbed by the mucosa can be controlled ${ }^{14,21}$

With regard to the retention and stability, the ideal system should provide good retentiveness ensuring stability to the prosthesis to prevent loss of retention capacity over time. It should be easy to maintain and have low replacement cost, and it should fit in small intermaxillary spaces focusing on aesthetics11-12,16-17,19. Another important feature is its biomechanical capacity to affect the distribution of functional loads exerted on the implants and the adjacent bone ${ }^{10.12}$. The literature reviewed revealed that the magnitude of the load depends on the number of implants, bone quality, length of cantilever, and the anteroposterior extent of the implants ${ }^{23}$.

As for the psychofunctional factors, the masticatory efficiency with traditional overdentures can be improved by $20 \%$ compared with the bite force of a total prosthesis ${ }^{24}$. Those who have impaired masticatory ability swallow larger pieces of food and therefore change their dietary selection by avoiding chewing more consistent foods. Consequently, these patients have reduced nutrient absorption. Dietary changes are based on the preference for softer foods that are easier to chew, such as processed foods, rather than food rich in fiber and nutrients, such as raw vegetables, meat, and fresh fruits ${ }^{23}$.

The maximum occlusal force of a patient with prosthesis can be improved by $300 \%$ with an Implantsupported prosthesis. Both overdenture and protocoltype prosthesis meet the needs of patients in terms of phonetics ${ }^{18}$. However, cases of bone loss with protocoltype prosthesis leading to possible escape of air and saliva flow have been reported, which does not occur with the use of overdentures ${ }^{18}$.

Oral hygiene is improved with an overdenture compared with a fixed prosthesis. Peri-implant probing is diagnostic and easier around a bar than a fixed prosthesis since the crown often prevents straight line access along the abutment to the crest of the bone ${ }^{23}$. An advantage of overdenture prosthesis is its easy hygiene, which is especially beneficial for patients with motor coordination problems. 
Financial status usually limits the access to a proper treatment, which may include two or three implants to anchor the overdenture. The major disadvantage of a mandibular overdenture is related to the patient's desire, especially when the patient does not want a removable prosthesis. If the edentulous patient wants to a removable prosthesis, overdenture is usually the best option. Patients subjected to oral rehabilitation demand effective treatments that are fast and convenient

The advantages and disadvantages of overdenture compared with fixed prosthesis are: advantages - less implants, better aesthetic outcome, easy to care for and clean, improved peri-implant probing, can be removed at night to decrease the risk of nocturnal parafunctional overload, lower cost, easier to repair, and can be used as a provisional or temporary prosthesis until the permanent fixed prosthesis is fabricated; disadvantages - psychological factor (since it is a removable device), space required to accommodate the necessary bulk for the tissue bar and any retaining clips, long-term maintenance, continuous posterior bone loss, food impaction, and movement (RP-5).

\section{REFERENCES}

1. Da Rosa DM, Zardo CM, Neto JS. Alternativas protéticas em implantodontia. In: Da Rosa DM, Zardo CM, Neto JS. Odontologia estética e a prótese fixa dentogengival. São Paulo: Artes Médicas; 2003. P. 91-119.

2. Critcholow SB, Ellis JS. Prognostic indicators for conventional complete denture therapy: a review of the literature. J Dent. 2010;38(1):2-9. doi: 10.1016/j.jdent.2009.08.004

3. Greco GD, Jansen WC, Landre J, Janis S, Isaías P. Biomechanical analysis of the stresses generated by different disocclusion patterns in an implant-supported mandibular complete denture. J Appl Oral Sci. 2009;17(5):515-20. doi: 10.1590/S167877572009000500029

4. Melescanu M, Marin M, Preoteasa E, Tancu AM, Preoteasa CT. Two implant overdenture - the first alternative treatment for patients with complete edentulous mandible. J Med Life. 2011;4(2):207-9.

5. Awad MA, Lund JP, Dufresne E, Feine JS. Comparing the efficacy of mandibular implant-retained overdentures and conventional dentures among middle-aged edentulous patients satisfaction and functional assessment. Int J Prosthodont. 2003;16(2):117-22.

6. Feine JS, Carlsson GE, Awad MA, Chehade A, Duncan WJ, Gizani S, et al. The Mcgill consensus statement on overdentures. Montreal, Quebec, Canada, May 24-25. Int J Prosthodont. 2002;15(4):413-4.

\section{CONCLUSION}

The choice between overdenture and Branemark protocol prosthesis will basically depend on the possibility of placing a suitable number of implants at the appropriate location, taking into account the patient's economic status.

\section{Collaborators}

HCR ALMEIDA contributed to data gathering, analysis, and interpretation, as well as flowchart drawing and manuscript writing. ETS SANTANA contributed to the search and organization of articles published in Spanish as well as to the comparison and discussion of the articles identified. NAT SANTOS contributed to the search and organization of articles published in Portuguese as well as to the comparison and discussion of the articles identified. PKM MORAES contributed to the search and organization of articles published in English, as well as to the comparison and discussion of the articles identified. YRF ARAÚJO contributed to organizing the references matching the requirements of this journal, spatial analysis, and manuscript writing. MEMM GERBI contributed to reading all full-text articles identified in the search and to manuscript writing.

7. van Kampen F, Cune M, van der Bilt A, Bosman F. The effect of maximum bite force on marginal bone loss in mandibular overdenture treatment: an in vivo study. Clin. Oral Implants Res. 2005;16(5):587-93. doi: 10.1111/j.1600-0501.2005.01121.x

8. Bakke M, Holm B, Gotfredsen K. Masticatory function and patient satisfaction with implant-supported mandibular overdentures: a prospective 5-year study. Int J Prosthodont. 2002;15(6):575-81.

9. Freeman C, Brook I, Joshi R. Long term follow-up of implantstabilised overdentures. Eur J Prosthodont Rest Dent. 2001:9(3/4):147-50

10. Avelar RP. Design dos implantes e implicações mecânicas, funcionais e estéticas. Implant News. 2005;2(5):574-5.

11. Carvalho PSP, Bassi APF, Garcia Junior IR, França MT, Ponzoni D. Enxerto de calota craniana para reconstrução de processo alveolar de maxila atrófica: Técnica de obtenção e dificuldades transoperatórias. Implant News. 2006;3(6):572-7.

12. Burns DR. Mandibular implant overdenture treatment: Consensus and controversy. J Prosthodont. 2000;9(1):37-46.

13. Mericske-Stern R. Treatment out comes with implant-supported overdentures: Clinical considerations. J Prosthet Dent. 1998;79(1):66-73. doi:10.1016/S0022-3913(98)70196-9

14. Agliardi E, Panigatti S, Clericò M, Villa C, Malò P. Immediate rehabilitation of the edentulous jaws with full fixed prostheses supported by four implants: interim results of a single cohort 
prospective study. Clin Oral Implants Res. 2010;21(5):459-65. doi: 10.1111/j.1600-0501.2009.01852.x.

15. Cooper L, De Kok IJ, Reside GJ, Pungpapong P, Rojas-Vizcaya F. Immediate fixed restoration of the edentulous maxilla after implant placement. J Oral Maxillofac Surg. 2005:63(9Suppl):S97S110. doi: 10.1016/j.joms.2005.05.157

16. Drago C, Carpentieri J. Treatment of maxillary jaws with dental implants: guidelines for treatment. J Prosthodont. 2011;20(5):336-47. doi: 10.1111/j.1532-849X.2011.00717.x

17. Cordeiro Filho C, Gouvêa CVD, Duarte CL, Monte Alto RV, Pinheiro AR. Overdeture mandibular com carga imediata em implantes de corpo único. Implant News. 2010;7(3):339-407.

18. Silva MAB, Consani RLX, Oliveira GJPL, Reis JIL, Fontanari LA, Reis JMSN. Associação entre implantes odontológicos e próteses parciais removíveis: revisão de literatura. RSBO. 2011;8(1):97101.

19. Awad MA, Feine JS. Measuring patient satisfaction with mandibular prostheses. Community Dent Oral Epidemiol. 1998;26(6):400-5.

20. Bilt AV, Burger M, Kampen FMC, Cune MS Mandibular implant-supported overdentures and oral function. Clin Oral
Implants Res. 2010;21(11):1209-13. doi: 10.1111/j.16000501.2010.01915.x

21. Yang T, Maeda Y, Gonda Y, Kotecha S. Attachment systems for implant overdenture: influence of implant inclination on retentive and lateral forces. Clin Oral Implants Res. 2011;22(11):1315-9. doi: 10.1111/j.1600-0501.2010.02137.x

22. Heydecke G, Boudrias P, Awad MA, De Albuquerque RF, Lund $J P$, Feine JS. Withinsubject comparisons of maxillary fixed and removable implant prostheses: Patient satisfaction and choice of prosthesis. Clin Oral Implants Res. 2003;14(1):125-30. doi:

23. Borges Tde F1, Mendes FA, de Oliveira TR, do Prado CJ, das Neves FD. Overdenture with immediate load: mastication and nutrition. Br J Nutr. 2011:105(7):990-4. doi: 10.1017/ S000711451000471X
Received on: 14/11/2014

Final version resubmitted on: 27/3/2015

Approved on: 9/4/2015 
